\title{
Gadolinium-based contrast agent-induced neurotoxicity: seeing is believing!
}

\author{
Gaurav Chauhan (D) , ${ }^{1}$ Aman Upadhyay ${ }^{2}$
}

${ }^{1}$ Chronic Pain Division, Department of Anesthesiology and Perioperative Medicine, UPMC, Pittsburgh, Pennsylvania, USA

${ }^{2}$ Anesthesiology, Pain Management and Perioperative Medicine, Henry Ford Health System, Detroit, Michigan, USA

Correspondence to Dr Gaurav Chauhan: CHAUHANG@UPMC.EDU

Accepted 9 January 2021

\section{DESCRIPTION}

Gadolinium-based contrast agents (GBCAs) are widely used in imaging today. GBCAs are used in $25 \%$ of all MRI examinations and, at times, are used to facilitate the fluoroscopic-guided interventional procedures associated with chronic pain. Gadolinium, $\mathrm{Gd} 3+$, is the most paramagnetic element practically available. GBCAs are ideal for enhancing MRI. Gadolinium is a toxic element. Linear or macrocyclic chelating compounds (ie, polyaminocarboxylic acid formulations) reduce the toxicity of the metal and increase its elimination. Following intravenous injection, GBCAs are distributed in the blood and extracellular tissue and are rapidly eliminated by the kidneys. The intravenous application of GBCAs has been considered relatively safe and benign. However, the impact of GBCAs on human health and their mechanism of toxicity is mostly unknown. ${ }^{12}$

GBCAs are also used as an alternative to iodinated contrast agents for neuraxial procedures routinely performed by interventional pain physicians. ${ }^{3}$ A patient with chronic pain with shellfish allergy inadvertently received $2 \mathrm{~mL}$ of gadobutrol (a type of GBCA) intrathecally during lumbar epidural steroid injection, which was confirmed fluoroscopically (figure $1 \mathrm{~A}, \mathrm{~B}$ ).
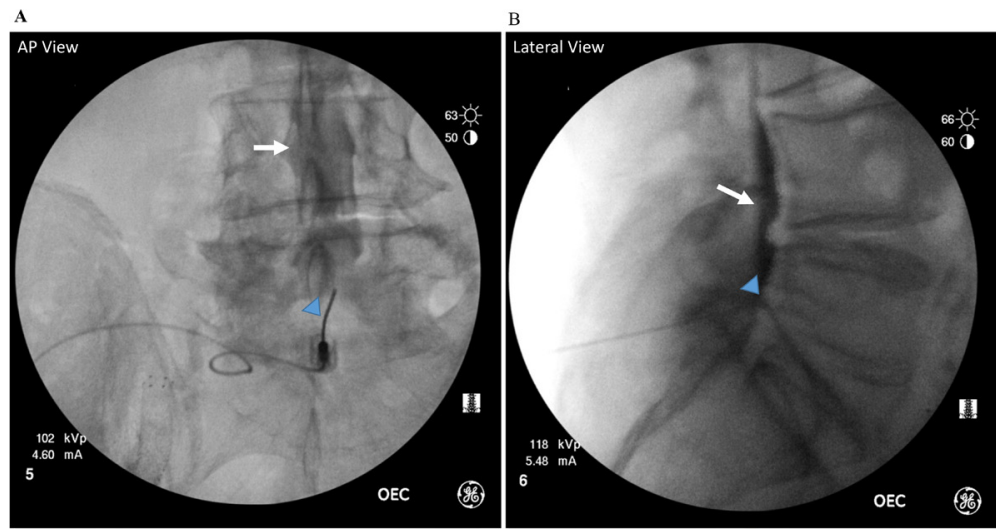

Figure 1 (A) Anteroposterior fluoroscopic view of the lumbar spine shows flat glass-like appearance of gadobutrol contrast (white arrow) as opposed to a patchy honeycomb appearance in the epidural space with 18-gauge Quincke spinal needle at the L5-S1 level (blue arrowhead). (B) Lateral fluoroscopic view of the lumbar spine shows gadobutrol contrast outlining the thecal sac (white arrow) and the tip of 18-gauge Quincke spinal needle in the intrathecal space (blue arrowhead). AP, anteroposterior.
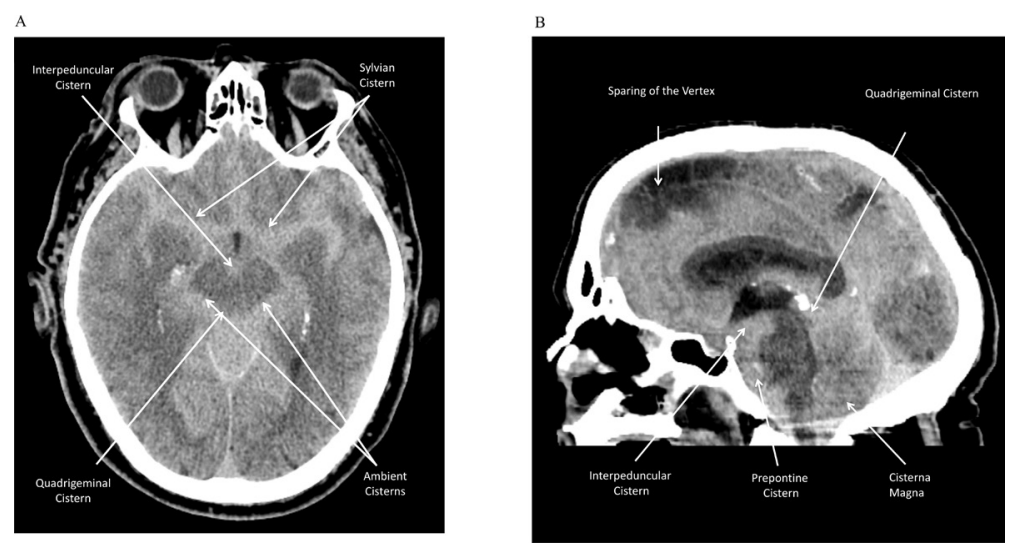

Figure 2 (A) Non-contrast CT scan of the coronal section of brain shows diffuse large-volume hyperattenuation throughout the subarachnoid spaces in the quadrigeminal cisterns, interpeduncular cistern, prepontine cistern and cisterna magna with sparing of the vertex. (B) The sagittal section on CT scan shows hyperattenuation of Sylvian cisterns, ambient cisterns, quadrigeminal cisterns and interpeduncular cistern. 


\section{Patient's perspective}

I had this procedure multiple times in the past, but this time it felt different. I started feeling sick to my stomach and developed a bad headache. I thought I was having a stroke. I was sweating a lot and then I started seeing a lot of colours. I remember hearing a lot of noises. I woke up with the intense feeling of dryness in my mouth and a gagging sensation. I felt nauseous and still had a bad headache. I could barely open my eyes as the lights were blinding me and I had some sort of cream in my eyes. My hands were tied, which scared me. I had a bad itch in my throat, but I could not do anything. I also felt very cold and started shivering. I vaguely remember a shadow coming close to me and trying to talk to me. I could not understand a word. I started feeling sleepy again. I was very very scared. I woke up again and my room was dark. I again had a gagging sensation and intense pain in my throat. I again remember someone coming close to me, and I thought that they would hurt me. I started to fight but my hands were tied. I started kicking and then I heard my wife's voice. I could barely understand what she and the other person was saying. After few minutes, I could see their faces. I wanted to yell and scream at her. I was very angry. Then the other person told me that I had a bad reaction in the pain clinic, and I was in intensive care unit for 2 days. I could not believe. I thought I was still in the clinic. I wanted them to help me with the gagging sensation in my throat. They made me sit and I could see a lot of wires. They gave me a paper to write but I could barely hold the pen. I pointed out towards my throat and I was extremely angry. I had lot of pain in my throat, but I could see more clearly and hear more noises from outside my cabin. My wife was with me. She was crying and told me that I almost died. At that point the only thing I cared was the dryness in my mouth and the gagging sensation. I also started feeling nauseous and my back and head stated hurting. After a few minutes, more people entered the room, and they removed a big tube from my stomach. I coughed violently and stated spitting. I couldn't talk at first. I again got scared. I thought that I had a stroke, and my voice is gone. My mouth was very dry and crusty; I had a bad headache and I felt very very tired. I took some sips and chewed on a wet sponge. After a while I could speak, and I asked for my pain doctor. My wife told me that I was in coma for 2 days and I almost died. I was still angry at her for leaving me like this. I tried to move my arms and my legs to make sure they are working. The pain doctor came in after some time and explained to me what happened. I remember the pain doctor coming to see me in the cabin. He also explained to me what happened. I was relieved that I did not have a stroke.

Within $30 \mathrm{~min}$ of injection, the patient reported severe headache, confusion and aphasia, along with generalised tonicclonic seizures. The patient was emergently intubated. Brain imaging performed within 2 hours of intrathecal injection was notable for contrast diffusely in the subarachnoid space. A diffuse large-volume hyperattenuation was present throughout the subarachnoid space on a CT scan of the brain (figure 2A). There was hyperattenuation of the Sylvian, ambient, quadrigeminal and interpeduncular cisterns by CT imaging (figure $2 \mathrm{~B}$ ).

The patient made a full recovery within 72 hours. GBCAs have varying molar concentrations, and similar volume limits cannot be used across different GBCAs. Moreover, the safe dose limit of $2.5 \mu \mathrm{mol} / \mathrm{g}$ brain tissue, based on animal studies, fails to correlate with humans as humans may be more sensitive to intrathecal GBCA than animals. ${ }^{4} 5$ The authors conclude that GBCAs may cause catastrophic neurological injury, and proceduralists should exercise caution when using GBCAs during interlaminar epidural steroid injections.

\section{Learning points}

- Gadolinium-based contrast agents (GBCAs) when injected intrathecally, an off-label use, may lead to severe neurological sequelae; caution should be exercised during procedures employing these agents.

- Physicians should be aware of 'gadolinium encephalopathy' as a clinical entity. A treatment algorithm should be in the facility for inadvertent intrathecal injection of GBCAs.

- lodinated contrast agents can be used in patients with shellfish allergy.

Contributors GC: drafted the manuscript and performed the literature search and proofreading. AU: treated the patient, was involved in clinical care and defined the intellectual content of the manuscript.

Funding The authors have not declared a specific grant for this research from any funding agency in the public, commercial or not-for-profit sectors.

Competing interests None declared.

Patient consent for publication Obtained.

Provenance and peer review Not commissioned; externally peer reviewed.

ORCID iD

Gaurav Chauhan http://orcid.org/0000-0003-4468-1808

\section{REFERENCES}

1 Aime $S$, Caravan P. Biodistribution of gadolinium-based contrast agents, including gadolinium deposition. J Magn Reson Imaging 2009;30:1259-67.

2 Malikova H, Holesta M. Gadolinium contrast agents - are they really safe? J VasC Access 2017;28:1-7

3 Popescu A, Patel J, McCormick ZL, et al. Fact finders for patient safety: are gadoliniumbased contrast media safe alternatives to iodinated contrast agents for the safe performance of spinal injection procedures? Pain Med 2018;19:2089-90.

4 Park K-W, Im S-B, Kim B-T, et al. Neurotoxic manifestations of an overdose intrathecal injection of gadopentetate dimeglumine. J Korean Med Sci 2010;25:505-8.

5 Provenzano DA, Pellis Z, DeRiggi L. Fatal gadolinium-induced encephalopathy following accidental intrathecal administration: a case report and a comprehensive evidencebased review. Reg Anesth Pain Med 2019;44:721-9. 
Copyright 2021 BMJ Publishing Group. All rights reserved. For permission to reuse any of this content visit https://www.bmj.com/company/products-services/rights-and-licensing/permissions/

BMJ Case Report Fellows may re-use this article for personal use and teaching without any further permission.

Become a Fellow of BMJ Case Reports today and you can:

- Submit as many cases as you like

- Enjoy fast sympathetic peer review and rapid publication of accepted articles

Access all the published articles

Re-use any of the published material for personal use and teaching without further permission

Customer Service

If you have any further queries about your subscription, please contact our customer services team on +44 (0) 2071111105 or via email at support@bmj.com.

Visit casereports.bmj.com for more articles like this and to become a Fellow 